\title{
CHARACTERIZATION OF THE GENOTYPES OF CHILDREN AND ADULTS RESIDING IN THE CONDITIONS EXPOSED TO THE CHEMICAL RISK FACTORS
}

\author{
O.V. Dolgikh ${ }^{1,2,3}$, A.V. Krivtzov ${ }^{1}$, O.A. Bubnova ${ }^{1,3}$, K.G. Starkova ${ }^{1}$, \\ V.A. Luchnikova ${ }^{1}$, E.A. Pirogova ${ }^{1}$ \\ ${ }^{1}$ FBSI "Federal Scientific Center for Medical and Preventive Health Risk M anagement Technologies", \\ Russian Federation, Perm, 82, M onastyrskaya St., 614045, \\ ${ }^{2}$ Perm National Research Polytechnic University, Russian Federation, Perm, 29, Komsomolsky prospekt, 614990, \\ ${ }^{3}$ Perm State National Research University, Russian Federation, Perm, 15, Bukireva St., 614990
}

We conducted the comparative assessment of the results of immune diagnostics and analysis of polymorphism of genes in children exposed to the aero-technogenic contaminants with the genotypes of their parents. We established the genetic polymorphism of detoxication genes CYP1A1, CPOX, SULT1A1 as well as the alternative allelism of genes characterizing the condition of the endothelium of vessels (VEGF and eNOS) both for children and their parents. The presented data evidence the genetic fixation of minor genotypes of parents in children exposed to the chemical risk factors. factors.

Key words: aerogenic external environmental load, polymorphism of genes, genetic fixation, detoxication genes, risk

It is urgent to carry out the objective and credible assessment of the detoxication systems and polymorphism of genes for population in the conditions of increased technogenical chemical load using the modern diagnostic molecular and genetic technologies [1-4, 7-11]. The analysis and use in future of the modern genetic diagnostic criteria, first of all detoxication genes of the $1^{\text {st }}$ and 2 ns stage, will allow for extending the evidentiary base on the detection of the cause-and-effect relationships of pathological and premorbid conditions stipulated by the impact of chemical living environment factors $[5,6,12]$.

The purpose of study was the comparative analysis of genetic markers in the children and adults residing in the conditions exposed to the chemical risk factors.

Materials and methods. The district of large industrial city with developed chemical industry was selected as the territory of observation. The leading factors of aerogenic external environmen- tal load at the territory include formaldehyde (exceeding of the average daily maximum permissible concentration up to 3.57 ); phenol (up to 1.42 of the average daily maximum permissible concentration), benz(a)pyrene (up to 5.41 of the average daily maximum permissible concentration). The priority route of intake of harmful substances is inhalatiton. The district with permissible level of chemical impact is selected as the control conventionally clean territory. We examined the children ( 75 persons) permanently residing and visiting the children preschool institutions (CPI) in the corresponding districts as well as the adults (parents of children) in the number of 36 persons.

The sampling of material for polymerase chain reaction (PCR) was by taking the swabs from the mucous membrane of oral pharynx. Further we extracted the DNA using the sorbent method which is based on the destruction of cells with further sorption of nucleic acids on the sorbent.

(C) Dolgikh O.V., Krivtzov A.V., Bubnova O.A., Starkova K.G., Luchnikova V.A., Pirogova E.A., 2015

Dolgikh Oleg Vladimirovich - doctor of medical sciences, professor, head of immune-biological diagnostic methods department, professor of the human ecology and life safety department, professor of the environment protection department (e-mail: oleg@fcrisk.ru; tel. (342) 236-39-30).

Krivtsov Aleksandr Vladimirovich - candidate of medical science, head of immunegenetics laboratory (e-mail: krivtsov@fcrisk.ru; tel. +7 (342) 236-39-30).

Bubnova Olga Alekseevna - junior research assistant of the immune-biological diagnostic methods department (email: oleg@fcrisk.ru; tel. +7 (342) 236-39-30).

Starkova Kseniya Gennadyevna - candidate of medical science, head of immunology and allergology laboratory (e-mail: oleg@ fcrisk.ru; tel. +7 (342) 236-39-30).

Luchnikova Viktoria Aleksandrovna - junior research assistant of the immune-biological diagnostic methods department, associate professor of the human ecology and life safety department (e-mail: oleg@ @crisk.ru; tel. +7 (342) 236-39$30)$.

Pirogova Elena Alekseevna - junior research assistant of the immune-biological diagnostic methods department (email: oleg@fcrisk.ru; tel. +7 (342) 236-39-30). 
To study the polymorphic options in the examined genes we used the PCR methods which are based on the reaction of on-line amplification and detection of the products of this reaction using the fluorescent markers. The primers used for the reaction of amplification are preliminary labeled by these markers. Different markers and probes are used for simultaneous detection of several reaction products (multiplex PCR). The DNA section of genes CYP1A1, CPOX, VEGF, eNO-synthase, SULT1A1 was used as primers. To determine the human genotype we used the allelic discrimination method when the differences between heterozygotes and homozygotes of wild and minor options were established under the differences of reactions of amplification of the corresponding primers.

The processing of genetic typing data was performed using the unified program "Gene Expert". This program is used for the calculation of statistical parameters for "case - control" studies using SNP (single nucleotide polymorphism diagnostics). To describe the balance in the frequency of genotypes and alleles of genes according to Hardy-Veinberg equilibration we used the statistical methods.

Results and their discussion. We analyzed the peculiarities of single nucleotide polymorphisms in the adults residing in the conditions of combined multifactorial chemical exposure to technogenic factors and fixation of the changed genotype in children also residing at this territory (table).

It was established that polymorphism of detoxication gene CYP1A1 differs by the predominant negative deviations in the children of main group since the heterozygous option of CPOX genotype is specific for the adults of the main group being fixed hereditably in the form of pathological homozygote at the level exceeding the same prevalence of genotype in adults by 3 times. The increased prevalence of heterozygous genotype of sulphatase gene (SULT1A1) characterizes the peculiarities of polymorphism both for the adults and children of the main group.

Comparative polymorphism of genes in the children and their parents exposed to the chemical technogenic factors

\begin{tabular}{|c|c|c|c|c|c|c|}
\hline \multirow{2}{*}{ Indicator } & \multirow{2}{*}{ Genotype } & \multicolumn{2}{|c|}{ Adults } & \multirow{2}{*}{ Genotype } & \multicolumn{2}{|c|}{ Children } \\
\hline & & main & control & & main & control \\
\hline \multirow{5}{*}{ Cytochrome gene P-450 } & GG & $93 \%$ & $94 \%$ & GG & $92 \%$ & $93 \%$ \\
\hline & $\mathrm{AG}$ & $6 \%$ & $4 \%$ & $\mathrm{AG}$ & $8 \%$ & $7 \%$ \\
\hline & $\mathrm{AA}$ & $1 \%$ & $2 \%$ & AA & $0 \%$ & $0 \%$ \\
\hline & $\mathrm{G}$ & 96 & 96 & $\mathrm{G}$ & 96 & 97 \\
\hline & $\mathrm{A}$ & 4 & 4 & $\mathrm{~A}$ & 4 & 3 \\
\hline \multirow{5}{*}{$\begin{array}{l}\text { Gene CPOX } 1 \\
\text { (coproporphyrin- } \\
\text { genoxidase) }\end{array}$} & AA & $62 \%$ & $65 \%$ & GG & $70 \%$ & $66 \%$ \\
\hline & $\mathrm{CA}$ & $37 \%$ & $35 \%$ & GA & $27 \%$ & $33 \%$ \\
\hline & $\mathrm{CC}$ & $1 \%$ & $0 \%$ & $\mathrm{AA}$ & $3 \%$ & $1 \%$ \\
\hline & $\mathrm{A}$ & 80 & 83 & A & 83 & 83 \\
\hline & $\mathrm{C}$ & 20 & 17 & $\mathrm{C}$ & 17 & 17 \\
\hline \multirow{5}{*}{ Gene SULT1A1 } & GG & $27 \%$ & 27,3 & GG & $30 \%$ & 34,8 \\
\hline & GA & $61 \%$ & 54,5 & GA & $59 \%$ & 39,1 \\
\hline & AA & $12 \%$ & 18,2 & AA & $11 \%$ & 26,1 \\
\hline & G & 58 & 65 & $\mathrm{G}$ & 59 & 62 \\
\hline & $\mathrm{A}$ & 42 & 35 & $\mathrm{~A}$ & 41 & 38 \\
\hline \multirow{5}{*}{ Gene VEGF } & GG & $55 \%$ & $52 \%$ & GG & $50 \%$ & $50 \%$ \\
\hline & GC & $37 \%$ & $37 \%$ & GC & $40 \%$ & $40 \%$ \\
\hline & $\mathrm{CC}$ & $8 \%$ & $11 \%$ & $\mathrm{CC}$ & $10 \%$ & $10 \%$ \\
\hline & $\mathrm{G}$ & 73 & 70 & $\mathrm{G}$ & 71 & 70 \\
\hline & $\mathrm{C}$ & 27 & 30 & $\mathrm{C}$ & 29 & 30 \\
\hline \multirow{5}{*}{ Gene eNOS } & GG & $54 \%$ & $52 \%$ & GG & $47 \%$ & $60 \%$ \\
\hline & GT & $40 \%$ & $41 \%$ & GT & $44 \%$ & $34 \%$ \\
\hline & TT & $16 \%$ & $7 \%$ & TT & $9 \%$ & $6 \%$ \\
\hline & $\mathrm{G}$ & 74 & 74 & $\mathrm{G}$ & 69 & 77 \\
\hline & $\mathrm{T}$ & 26 & 26 & $\mathrm{~T}$ & 31 & 23 \\
\hline
\end{tabular}

The polymorphism of the tumor necrosis factor gene evidences the negative selection at the inhe- ritance and prevalence in children both of minor allele and adverse genotype options. We detected 
the increased prevalence of heterozygous option of the pathogenetic genes responsible for the condition of the vascular bed endothelium (VEGF, eNOS), and if the endothelial growth factor gene in the parents of main group did not differe from control, the homozygous option (TT) of NO-synthase gene provided the high level of heterozygous deviations in the offsprings.

The established genetic associations evidence the presence of negative genetic selection of the most of analyzed genes that is facilitated by the content of formaldehyde, phenol and benz(a)pyrene in the atmospheric air because such associations are not specific for control group.

Conclusions. Therefore, the conducted comparative assessment of results of immune diagnostics and analysis of polymorphisms of genes in children exposed to technogenic contaminants with the genotypes of their parents allowed for detecting the peculiarities of the genetic polymorphism of detoxication genes CYP1A1, CPOX, SULT1A1 as well as the allelism of immune competent genes and genes characterizing the vessel endothelium condition (VEGF and eNOS) in the children and their parents. The provided data evidence the genetic fixation in children of the existing polymorphisms of parents and increase in the prevalence of mutant alleles of genes of the endothelial growth factor and endothelial NO-synthase when exposed to the chemical risk factors (formaldehyde, phenol and benz(a)pyrene).

\section{References}

1. Dolgih O.V., Predeina R.A., Dianova D.G. Jeksperimental'naja ocenka vlijanija fenolov na immunoreguljaciju EX VIVO [Experimental assessment of phenols impact on the EX VIVO immune regulation]. Analiz riska zdorov'ju, 2014, no 1, pp. 83-87.

2. Zajceva N.V., Dianova D.G., Dolgih O.V. Osobennosti apoptoza u detej pri hronicheskom ajerogennom vozdejstvii fenola [Peculiarities of apoptosis in children at chronic aerogenic exposure to phenol]. Fundamental'nye issledovanija, 2014, no 2, pp. 56-59.

3. Izmerov N.F. Professional'nyj otbor v medicine truda [Professional selection in the occupational medicine]. N.F. Izmerov. Medicina truda i promyshlennaja jekologija, 2006, no 3, pp. 15.

4. Gorshkova K.G., Bubnova O.A., Maerova E.D., Dolgih O.V. Immunologicheskie i geneticheskie markery vneshnesredovoj jekspozicii stronciem [Immunological and genetic markers of the external environmental exposure to strontium]. Sanitarnyj vrach, 2014, no 3, pp. 72-74.

5. Dolgih O.V., Krivcov A.V., Bubnova O.A., Alekseev V.B. Osobennosti geneticheskogo polimorfizma u zhenshhin s ugrozoj nevynashivanija $\mathrm{v}$ uslovijah hronicheskoj ajerogennoj jekspozicii fenolami [Peculiarities of genetic polymorphism in women with the threat of premature delivery in the conditions of chronic aerogenic exposure to phenols]. Analiz riska zdorov'ju, 2013, no 4, pp. 77-81.

6. Ustinova O.Ju., Luzheckij K.P., Maklakova O.A., Zemljanova M.A., Dolgih O.V., Ulanova T.S. Patogeneticheskie zakonomernosti kaskadnogo mehanizma razvitija hronicheskih gastroduodenal'nyh zabolevanij u detej, obuslovlennyh potrebleniem pit'evoj vody nenadlezhashhego kachestva po soderzhaniju produktov giperhlorirovanija i marganca [Pathogenetic regularities of cascade mechanism of the development of chronic gastroduodenal diseases in children stipulated by the consumption of potable water of improper quality undrr the content of hyperchlorination products and manganese]. Analiz riska zdorov'ju, 2014, no 3, pp. 61-70.

7. Approaches to the evaluation of chemical-induced immunotoxicity. K Krzystyniak [et. al.]. Environ Health Perspect, 1995, no 103, suppl 9, pp. 17-22.

8. Effects of resveratrol on human immune cell function. R. Falchetti [et. al.]. Life Sci., 2001, vol. 70, no 1, pp. 81-96.

9. Immunotoxicilogy: suppressive and stimulatory effects of drugs and environmental chemicals on the immune system. E. Gleichmann [et. al.]. Arch. Toxicology, 1989, no 63, pp. 257-273.

10. Influence of air pollution on humoral immune response. Stiller-Winkler R [et. al.]. J. Clin. Epidemiol, 1996, 49 (5), pp. 527-534.

11. Gervasi P.G., Longo V., Naldi F., Panattoni G., Ursino F. Xenobiotic-metabolizing enzymes in human respiratory nasal mucosa. Biochem Pharmacol, 1991, vol. 41, pp. 177-184.

12. Zaitseva N.V., Dianova D.G., Dolgykh O.V. Effects of cellular immunity in conditions of surplus supply of strontium with consumed water. European journal of natural history, 2014, no 1, pp. 7-8. 